\title{
Water Quality of Drainage Canals and Assessment of Nutrient Loads Using QUAL2Kw
}

\author{
Georgios D. Gikas
}

Received: 11 March 2014 / Accepted: 16 June 2014 / Published online: 8 July 2014

(C) Springer International Publishing Switzerland 2014

\begin{abstract}
The water quantity and quality in two of the four main drainage canals located in the plain of Chryssoupolis in Kavala, North Greece, are studied. The area is intensively used for agriculture. Irrigation water is supplied by Nestos River, using a network of irrigation canals. Drainage water and irrigation return flows are collected in the four main drainage canals, which outflow into the Thracian Sea, North Aegean. A monitoring program in the four canals was designed to monitor flow and main constituents of drainage water. Main pollutants included nitrate, phosphorus and suspended solids. Based on the collected data, the trophic state of the canals and its seasonal variation were assessed, and the limiting nutrient was identified. QUAL2Kw was also used to model flow and water quality in two of the four canals. The calibration and verification of QUAL2Kw was undertaken using the collected field data, in an effort to identify the pollution sources and propose future management actions for the improvement of drainage canal water quality. The results showed that QUAL2Kw is a useful tool to simulate water quality in rivers and canals, and to quantify the impacts of non-point source pollution from agricultural areas.
\end{abstract}

Keywords Drainage · Agricultural runoff · Nutrients · Water quality - QUAL2Kw · Trophic state

\section{Introduction}

The degradation of surface water quality is mostly due to anthropogenic factors, such as urbanization, and industrial and agricultural activities (Singh et al. 2005; Gikas et al. 2006a, b; Boskidis et al. 2010). The construction of wastewater treatment plants to control point-source pollution has highlighted non-point source pollution as the primary cause of poor water quality of aquatic systems (Novotny and Olem 1994). The most important non-point source polluter is agriculture, which enriches streams, rivers, lakes and the coastal areas with nutrients (nitrogen and phosphorus), sediments and pesticide residues. One result is the eutrophication of surface water bodies (Sylaios and Theocharis 2002; Kotti et al. 2005; Gikas et al. 2006b, 2009a, b).

Although the continuous monitoring of the water quality and the impact of human activities (e.g., agriculture) on aquatic systems is possible, this approach would be very expensive and

G. D. Gikas $(\triangle)$

Laboratory of Ecological Engineering and Technology, Department of Environmental Engineering,

Democritus University of Thrace, 67100 Xanthi, Greece

e-mail: ggkikas@env.duth.gr 
problematic, because by the time a problem in an aqueous system is detected, it may be too late to take action to address it (Wang et al. 2013). A better solution is to predict the impact of various practices (e.g., cultivation and others) on the surface water quality (rivers, lakes) using mathematical models; this allows for immediate action before detecting a problem, which may be very difficult to resolve afterwards. This practice has become very popular in recent years, and is very efficient in managing aquatic systems (Gikas et al. 2006a, 2009a; Fan et al. 2009; Boskidis et al. 2010, 2012).

QUAL2K is widely used in modeling the processes in rivers and canals, and in the evaluation of the impacts of agricultural pollutants, such as nutrients (N, P) (Chapra and Pelletier 2003). Typical recent examples include, among several others: QUAL2K was used to assess the hydraulic characteristics (flow and velocity) and water quality (water temperature, dissolved oxygen, electrical conductivity, $\mathrm{pH}$ and turbidity) of river Kancha in Brazil (Bottino et al. 2010). Rehana and Mujumdar (2011) used QUAL2K to simulate impact of six climate change scenarios on water quality response of Tunga-Bhadra river in India. Zhang et al. (2012) used QUAL2K in the Hongqi river to evaluate the effects of various scenarios on the improvement of water quality. Also, there are recent reports in the international bibliography regarding the later version of this model QUAL2Kw (e.g., Kannel et al. 2007a, b).

In this paper, we present: the results of a monitoring program in four drainage canals in Chryssoupolis plain, Kavala prefecture, Northern Greece, and the application of the model QUAL2Kw in two of these canals using field measurements, in order to simulate the flow and water quality of these systems. Specific objectives of the study were to: evaluate, based on collected data, the water quality of the drainage canals; and assess the temporal and spatial loads of nutrients $(\mathrm{N}$ and $\mathrm{P}$ ) from agricultural crops using QUAL2kw model.

\section{Methods and Materials}

\subsection{Study Area}

The study area is the Chryssoupolis plain, an area of approximately $190 \mathrm{~km}^{2}$, which is located in the western part of the Nestos river delta in Northern Greece $\left(40^{\circ} 56^{\prime} 51^{\prime} \mathrm{N}, 24^{\circ} 40^{\prime} 35^{\prime} \mathrm{E}\right.$; Fig. 1). The cultivated area covers about $138.6 \mathrm{~km}^{2}$. The following spring crops are mainly cultivated: corn, potatoes, tomatoes, rice and cotton, which cover $89.6 \%$ of the cultivated area. About $1.9 \%$ of the area comprises multiple crops (e.g., beans, corn) and $4.7 \%$ is tree farming (orchards, poplar). Finally, $3.1 \%$ of the cultivated land comprises winter crops, and $0.7 \%$ of the land remains uncultivated. The total nutrient quantities applied to Chryssoupolis plain, due to agricultural activities, are presented in Table 1; as seen, they are 5,812.0 tn/y and 713.9 tn/y for nitrogen and phosphorus, respectively.

The crops are irrigated with Nestos river water via a surface network of irrigation canals. Alongside, a network of drainage canals drains the area from rainwater runoff, collects return irrigation water and conveys it to the coast. Parts of this network are the following four main drainage canals (Fig. 1): T1 (length $16.6 \mathrm{~km}$, width 2-22 m), T2 (length $13.0 \mathrm{~km}$, width 1.5$2.0 \mathrm{~m}$ ), T3 (length $16.5 \mathrm{~km}$, width 3-8 m), T4 (length $15.1 \mathrm{~km}$, width $1.7-8.8 \mathrm{~m}$ ).

In the coastal area of Nestos Delta there is a series of nine coastal lagoons, which are of great ecological importance. They are protected by the Ramsar treaty and are part of the EU Natura 2000 network (Sylaios et al. 2006; Boskidis et al. 2011). The lagoons are used for aquaculture and contribute significantly to the local economy. In recent years, a decrease in fish production of this region has been observed, and the cause of this has been attributed to 


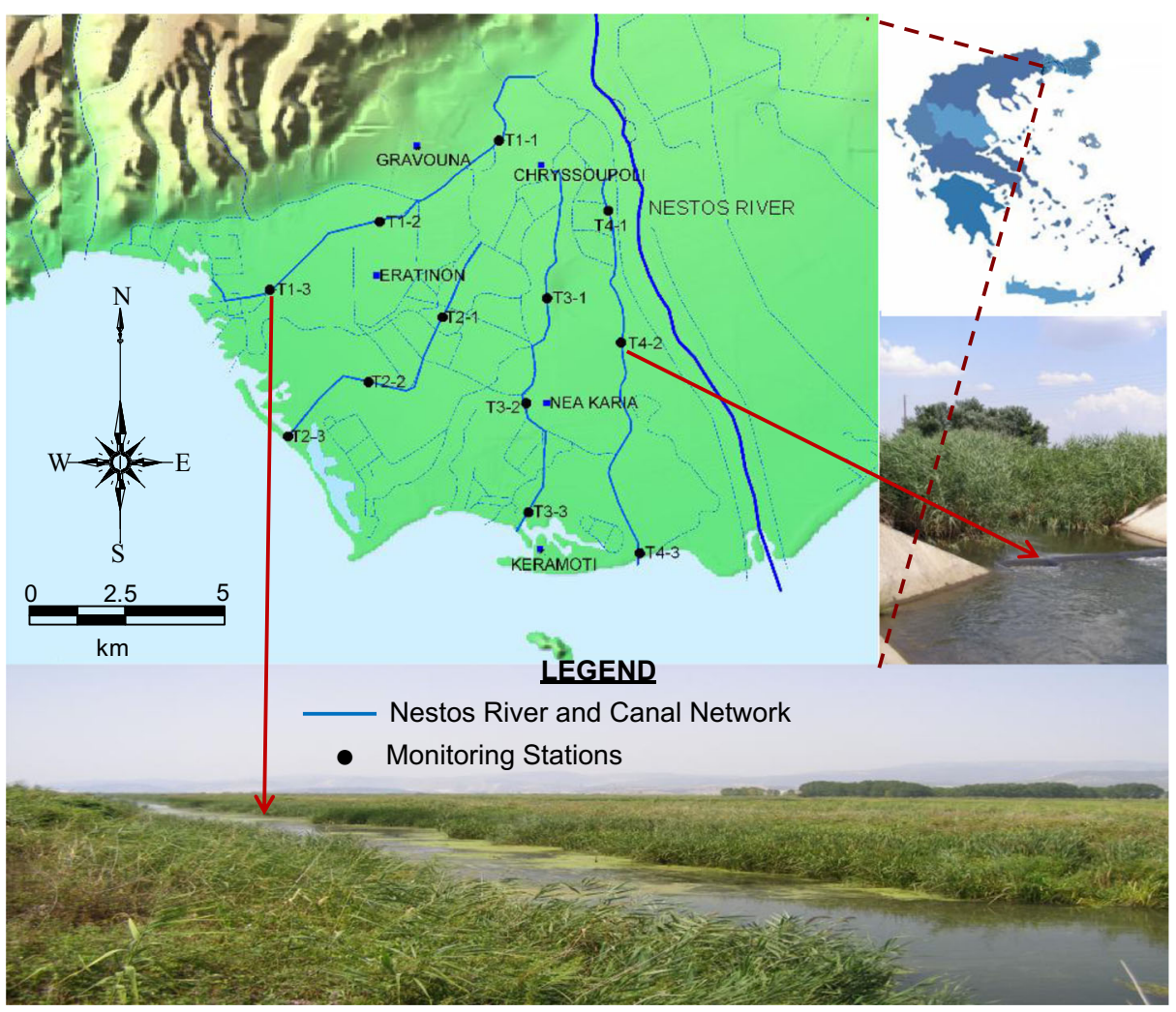

Fig. 1 Study area, drainage canals and monitoring stations

pollutants (nitrogen and phosphorus salts) entering the lagoons from point and non-point source pollution in this area (Sylaios et al. 2006).

\subsection{Water Quantity and Quality Monitoring}

For the purpose of this study, a data collection network was designed in the four main drainage canals to measure discharge and water quality variables at approximately 7 to 15 -day time intervals. In each canal, three monitoring and sampling stations were defined (T1-1 to T4-3; Fig. 1). The data collection period lasted from May 2006 to June 2008. Flow was measured using a Valeport model 801 flow meter. Temperature (T), dissolved oxygen (DO), electrical conductivity (EC) and $\mathrm{pH}$ were measured in situ. Samples were analyzed in the laboratory, in order to determine the concentrations of BOD and COD, total suspended solids (TSS), total Kjeldahl nitrogen $(\mathrm{TKN})$, ammonium nitrogen $\left(\mathrm{NH}_{4}-\mathrm{N}\right)$, nitrate $\left(\mathrm{NO}_{3}-\mathrm{N}\right)$ and nitrite $\left(\mathrm{NO}_{2}-\mathrm{N}\right)$ nitrogen, and ortho-phosphate (OP) and total phosphorus (TP), using standard methods (APHA 1998).

\subsection{QUAL2Kw Model Description}

The QUAL2Kw model is the newest and most improved version of QUAL2K, which is the evolution of the model QUAL2E (Pelletier and Chapra 2005; Pelletier et al. 2006; Turner et al. 


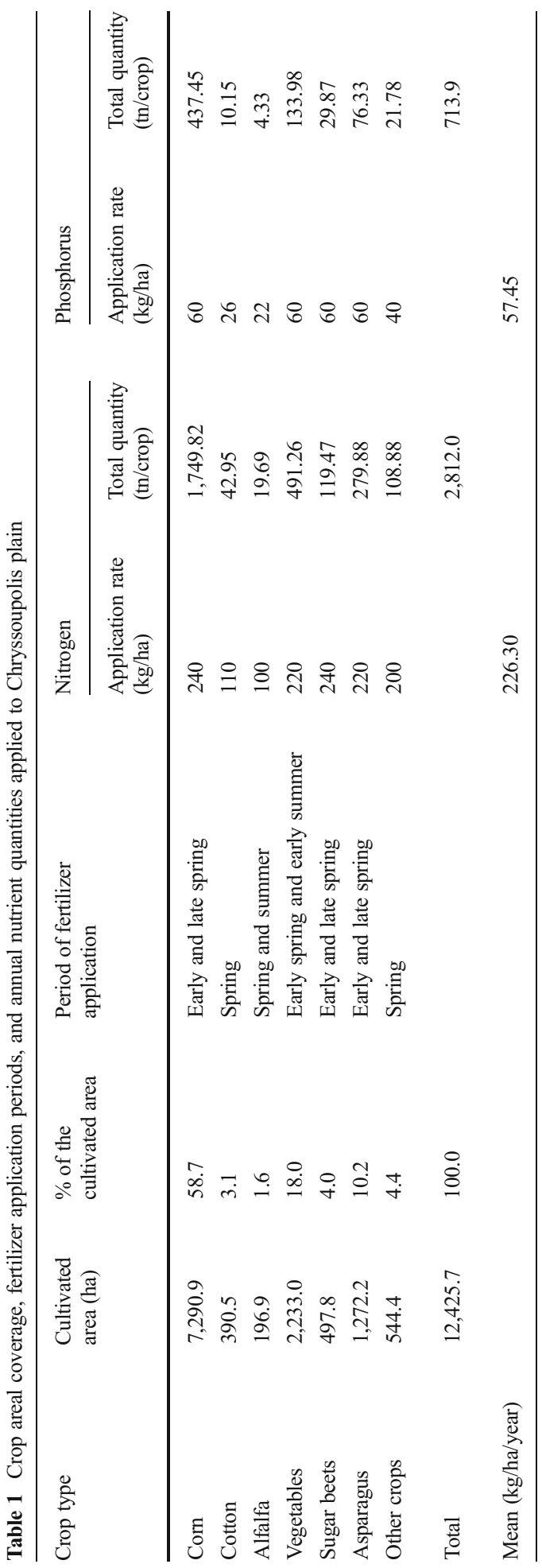


2009). It is a one-dimensional model, which has the ability to simulate the flow and quality of water in rivers and canals. More specifically, QUAL2Kw can simulate a number of constituents including temperature, dissolved oxygen, electrical conductivity, $\mathrm{pH}, \mathrm{BOD}$, suspended solids, ammonium nitrogen, nitrite and nitrate nitrogen, organic nitrogen, ortho-phosphate, organic phosphorus, total phosphorus and phytoplankton (Chapra and Pelletier 2003; Chapra et al. 2008; Pelletier et al. 2006).

To implement the model, the drainage canal is discretized into individual sections (reaches); in each reach mass balance is performed. Each reach is assumed to function as a complete mix reactor. The general mass balance equation used by the model to calculate the concentration of a constituent $\left(\mathrm{C}_{\mathrm{i}}\right)$, in a reach (i) is as follows (Chapra et al. 2008):

$$
\frac{d C_{i}}{d t}=\frac{Q_{i-1}}{V_{i}} C_{i-1}-\frac{Q_{i}}{V_{i}} C_{i}-\frac{Q_{a b, i}}{V_{i}} C_{i}+\frac{E_{i-1}}{V_{i}}\left(C_{i-1}-C_{i}\right)+\frac{E_{i}}{V_{i}}\left(C_{i+1}-C_{i}\right)+\frac{W_{i}}{V_{i}}+S_{i}
$$

where: $C_{i}$ is the constituent concentration at reach $i\left(g / \mathrm{m}^{3}\right) ; Q_{i}$ is the flow at reach $i\left(\mathrm{~m}^{3} / \mathrm{d}\right) ; V_{i}$ is the reach volume $\left(\mathrm{m}^{3}\right)$; $Q_{a b, i}$ is the flow abstraction from reach $\mathrm{i}\left(\mathrm{m}^{3} / \mathrm{d}\right) ; E_{\mathrm{i}}$ is the bulk dispersion coefficients between reaches $i$ and $i+1\left(\mathrm{~m}^{3} / \mathrm{d}\right) ; \mathrm{E}_{\mathrm{i}-1}$ is the bulk dispersion coefficients between reaches $\mathrm{i}-1$ and $\mathrm{i}\left(\mathrm{m}^{3} / \mathrm{d}\right) ; \mathrm{W}_{\mathrm{i}}$ is the external loading of the constituent to reach $\mathrm{i}$ $(\mathrm{g} / \mathrm{d}$ or $\mathrm{mg} / \mathrm{d}) ; \mathrm{S}_{\mathrm{i}}$ are sources/sinks of the constituent $\left(\mathrm{g} / \mathrm{m}^{3} /\right.$ day or $\mathrm{mg} / \mathrm{m}^{3} /$ day).

\subsection{Implementation and Calibration of QUAL2Kw}

The model was applied when flow was steady and was calibrated in two of the four drainage canals T1 and T4. To implement the model, the canals were divided into 15 and 16 reaches, respectively (Fig. 2). The main criterion of this division was the similarity of hydraulic characteristics in a canal reach, such as width and slope of the reach, vegetation, Manning roughness coefficient, etc.

The data input to the model was the canal discharge (from field measurements) and meteorological data that came from NOAA (National Oceanic and Atmospheric

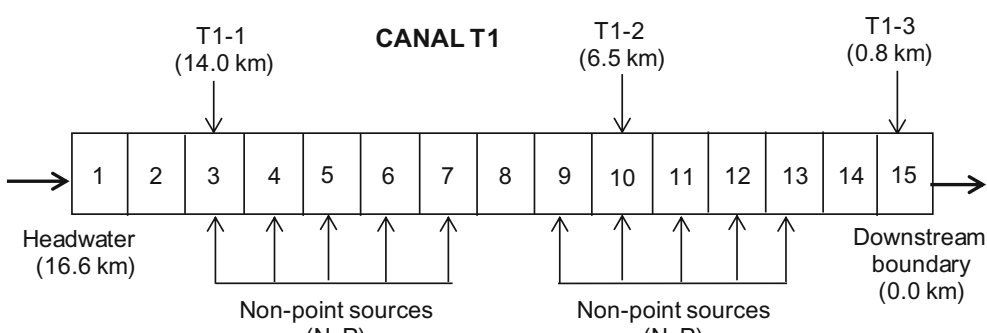

$(\mathrm{N}, \mathrm{P})$

$(\mathrm{N}, \mathrm{P})$

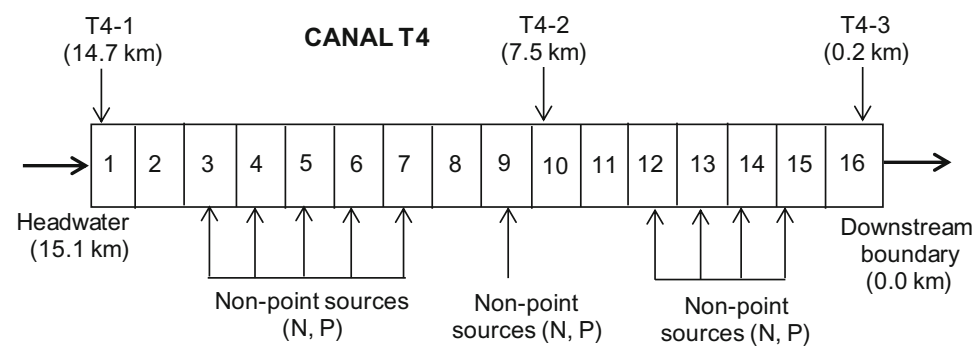

Fig. 2 Segmentation of drainage canals T1 and T4, location of monitoring stations and pollution sources 
Administration; http://www.ready.noaa.gov); these included air temperature, the dew point, wind speed and cloud cover.

The parameters for which the model was calibrated were: discharge, $\mathrm{pH}, \mathrm{EC}, \mathrm{NH}_{4}-\mathrm{N}, \mathrm{NO}_{3}$ $\mathrm{N}$ and OP. For calibration, the following steps were made: discharge was calibrated first, using as calibration variable the Manning roughness coefficient $n$, which assumed values from the literature (i.e., Chow 1959) and was varied within suggested limits; the final values ranged between 0.04 and 0.20 . The drainage canals receive water from non-point sources along almost their entire route due to irrigation (Fig. 2). The irrigation is not made simultaneously at all crops, at the same frequency and with the same amount of water. Therefore, in order to have agreement of the model results for the flow with the measured data at the three stations, additional amount of water was added $\left(\mathrm{m}^{3} / \mathrm{s}\right)$ at the reaches of the canal. This amount of water was another calibration variable.

Then, calibration for the various forms of nitrogen, such as ammonium and nitrate nitrogen, was made. In this case, the variables were the kinetic rates of nitrification and denitrification. Finally, a calibration for phosphorus, by adjusting the rate of hydrolysis of organic phosphorus, was made. The rates for nitrification, denitrification and hydrolysis of organic phosphorus varied within limits defined by the model and the final values were $2.00,0.01$ and $0.32\left(\right.$ day $\left.^{-1}\right)$, respectively. As in the case of discharge, it was necessary to add extra amounts of ammonium and nitrate nitrogen, and phosphorus from non-point sources, in order to minimize the error between the measured values in the field and those estimated by the model. The addition of nitrate and ammonium nitrogen and inorganic phosphorus was in concentration units $(\mu \mathrm{g} / \mathrm{L})$.

The accuracy of the calibration of the model was tested using the following methods: (a) the visual method, i.e., visual inspection of agreement in graphs displaying together values predicted by the model and those measured in the field (Gikas et al. 2006a); and (b) the calculation of the root mean square error (RMSE) and of the normalized objective function (NOF), computed based on the following equations:

$$
\begin{gathered}
R M S E=\sqrt{\frac{\sum_{i=1}^{N}\left(P_{i}-O_{i}\right)^{2}}{N}} \\
N O F=\frac{R M S E}{O_{\text {mean }}}
\end{gathered}
$$

where: $\mathrm{P}_{\mathrm{i}}$ and $\mathrm{O}_{\mathrm{i}}$ are the predicted and measured values, respectively; $\mathrm{O}_{\text {mean }}$ is the mean of measured values; and $\mathrm{N}$ is the number of measurements. The ideal values for the coefficient NOF is 0.0 . However, model predictions are acceptable for NOF values in the interval from 0.0 to 1.0 (Boskidis et al. 2010, 2011; Gikas et al. 2006a).

The model simulates the discharge of the canal and the water quality on a daily basis. The model was calibrated for year 2006 and for two periods, the cultivation season (from May to August) and the non-cultivation season (from October to December) of each month separately, because, as mentioned above, there are different cultivation conditions from month to month. The verification of the model was for the two corresponding periods of year 2007. The verification was used to compare different sets of field data and meteorological data, while for the input variables of the model (e.g., rates of nitrification, denitrification, etc.) the values obtained from the calibration of the model were maintained. 


\section{Results and Discussion}

\subsection{Monitoring Results}

Figure 3 presents box-whisker plots of the measured values of discharge, $\mathrm{T}, \mathrm{pH}, \mathrm{DO}, \mathrm{EC}, \mathrm{NO}_{\mathrm{x}}$ $\mathrm{N}\left(\mathrm{NO}_{3}-\mathrm{N}+\mathrm{NO}_{2}-\mathrm{N}\right), \mathrm{NH}_{4}-\mathrm{N}$ and TP. The box is defined by the lower and upper quartiles, and the median value is represented by the line at the center of the box. The caps at the end of each box indicate the extreme values (minimum and maximum) (Gikas and Tsihrintzis 2012).

Flow generally increased from inland stations towards the mouth of the canal to the sea (Fig. 3a). In canal T1, maximum measured discharge was $4.8 \mathrm{~m}^{3} / \mathrm{s}$ at station T1-3, while the mean discharge during all measurements was $1.64 \mathrm{~m}^{3} / \mathrm{s}$. Almost the same discharges were measured at stations T2-2 and T2-3 with mean discharge of 0.33 and $0.30 \mathrm{~m}^{3} / \mathrm{s}$, respectively, while the mean discharge at station T2-1 of canal T2 was $0.5 \mathrm{~m}^{3} / \mathrm{s}$; these values are lower than those in other canals, due to the small length and limited drainage area of canal T2. The low discharge at station T2-3 is due to the seawater intrusion (i.e., tidal effect). The flow was not measured at station T3-3, because the access was very difficult, but water samples were collected. Canal T3 had a maximum discharge of $3.25 \mathrm{~m}^{3} / \mathrm{s}$ at station T3-2 and a mean discharge of $1.31 \mathrm{~m}^{3} / \mathrm{s}$ at the same station, while in canal T4, a maximum discharge of $2.26 \mathrm{~m}^{3} / \mathrm{s}$ and a mean of $1.18 \mathrm{~m}^{3} / \mathrm{s}$ were measured at station T4-3.

The temperature in all canals showed normal seasonal variation, varying from $5.3^{\circ} \mathrm{C}$ in the winter to $25.8{ }^{\circ} \mathrm{C}$ in the summer, without significant change between the different canals (Fig. 3b). No significant variation was observed in $\mathrm{pH}$ and $\mathrm{DO}$ mean values. The mean spatial $\mathrm{pH}$ at all monitored sites varied from 7.47 to 7.64, and the mean DO values varied from 6.14 to $7.27 \mathrm{mg} / \mathrm{L}$ (Fig. 3c, d). The maximum conductivity values were recorded at stations T2-3 $(10.2 \mathrm{mS} / \mathrm{cm})$ and T3-3 $(1.72 \mathrm{mS} / \mathrm{cm})$, due to seawater intrusion (Figs. 1, 3e). In the remaining stations, the mean conductivity values varied from $0.44 \mathrm{mS} / \mathrm{cm}$ to $0.61 \mathrm{mS} / \mathrm{cm}$.

The mean concentrations of $\mathrm{NO}_{\mathrm{x}}-\mathrm{N}$ in canals $\mathrm{T} 1, \mathrm{~T} 2, \mathrm{~T} 3, \mathrm{~T} 4$, based on all measurements, were $1.48 \mathrm{mg} / \mathrm{L}, 1.01 \mathrm{mg} / \mathrm{L}, 1.31 \mathrm{mg} / \mathrm{L}$ and $1.01 \mathrm{mg} / \mathrm{L}$, respectively (Fig. 3f). Higher concentrations of $\mathrm{NO}_{\mathrm{x}}-\mathrm{N}$ were measured in all canals during the summer period and are attributed to agricultural activities, which enrich the canal water with nitrite and nitrate salts. The ammonium nitrogen concentration did not show significant variation between monitored stations, with the exception of station T3-3, where the mean concentration of ammonium was between 2.5 times (compared to T1-1) and 5.5 times (compared to T4-3) higher than that of the other stations (Fig. $3 \mathrm{~g}$ ). This fact may be due to the influence of a poultry farm operating at this location. Mean concentrations of $\mathrm{NH}_{4}-\mathrm{N}$ in canals T1, T2, T3, T4, based on all measurements, were $0.34 \mathrm{mg} / \mathrm{L}, 0.26 \mathrm{mg} / \mathrm{L}, 0.48 \mathrm{mg} / \mathrm{L}$ and $0.22 \mathrm{mg} / \mathrm{L}$, respectively. These values are more than one order of magnitude higher than the mean concentration of ammonia in the water of Nestos river (which supplies irrigation water) during the same period $(0.026 \mathrm{mg} / \mathrm{L}$; Boskidis et al. 2011), showing that agricultural activities enrich the canal water with ammonium salts. The mean concentrations of TP at stations T1, T2, T3, T4 were $0.07 \mathrm{mg} / \mathrm{L}, 0.11 \mathrm{mg} / \mathrm{L}$, $0.24 \mathrm{mg} / \mathrm{L}$ and $0.07 \mathrm{mg} / \mathrm{L}$, respectively (Fig. 3h). The significantly increased TP concentration observed at station T3-3 (mean value $0.57 \mathrm{mg} / \mathrm{L}$ ) may be again due to the influence of the poultry farm at this location.

The nitrogen to phosphorus (N/P) ratio is often used in the estimation of the limiting nutrient for algal production in aquatic systems. In algal cells the $\mathrm{N} / \mathrm{P}$ ratio (expressed as mass) is 7.2:1 (Redfield ratio) and is calculated based on dissolved inorganic nitrogen and orthophosphate (Gikas et al. 2006b; Gikas et al. 2009b). The N/P ratio at T1, T2, T3 and T4 canals during the monitoring period are presented in Fig. 4 and are compared to the ratio of 7.2:1. During the entire monitoring period the N/P ratio at T1-1, T1-2, T1-3, T2-1, T2-2, T3-1, T3-2, 

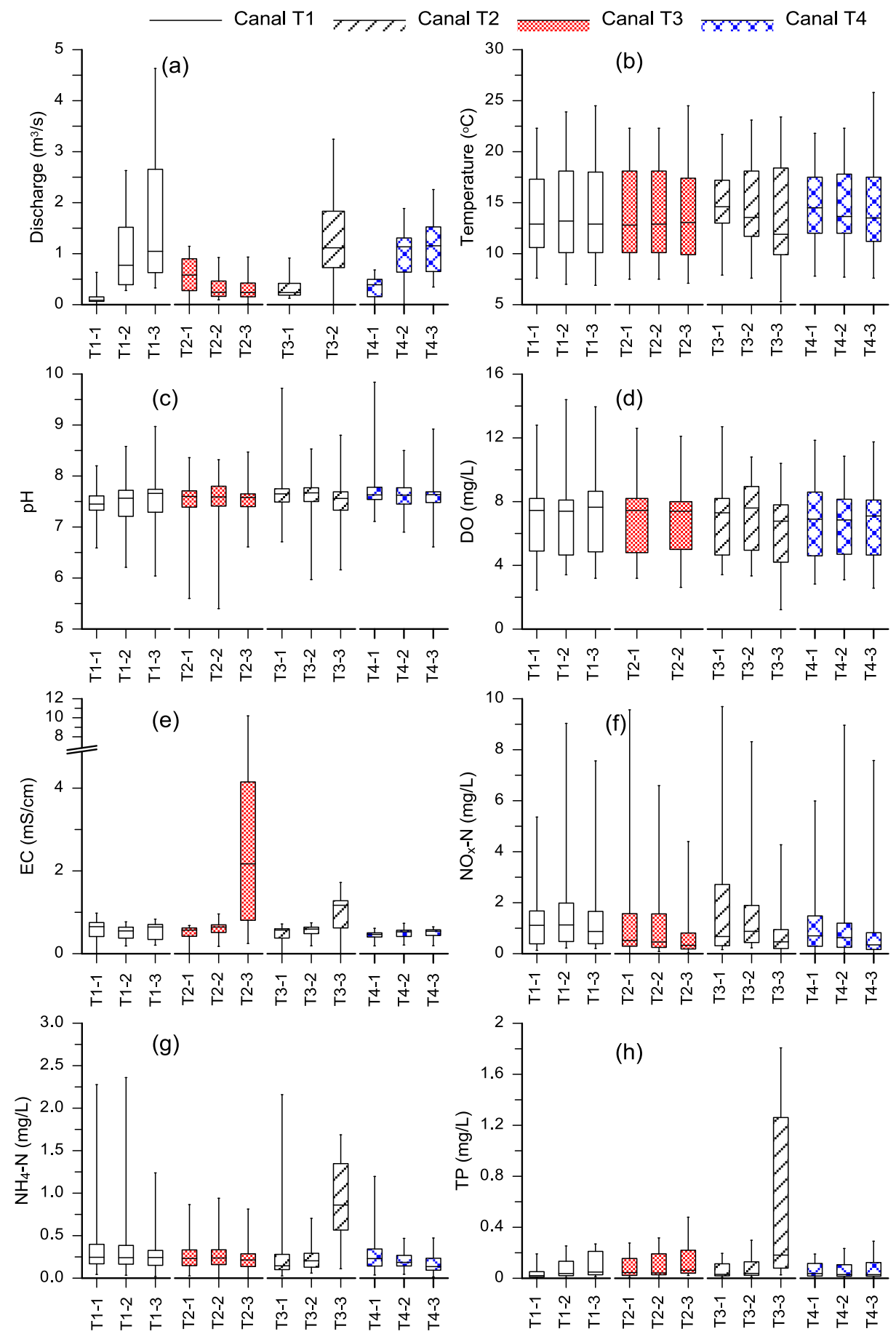

Fig. 3 Box-whisker plots of selected measured parameters 


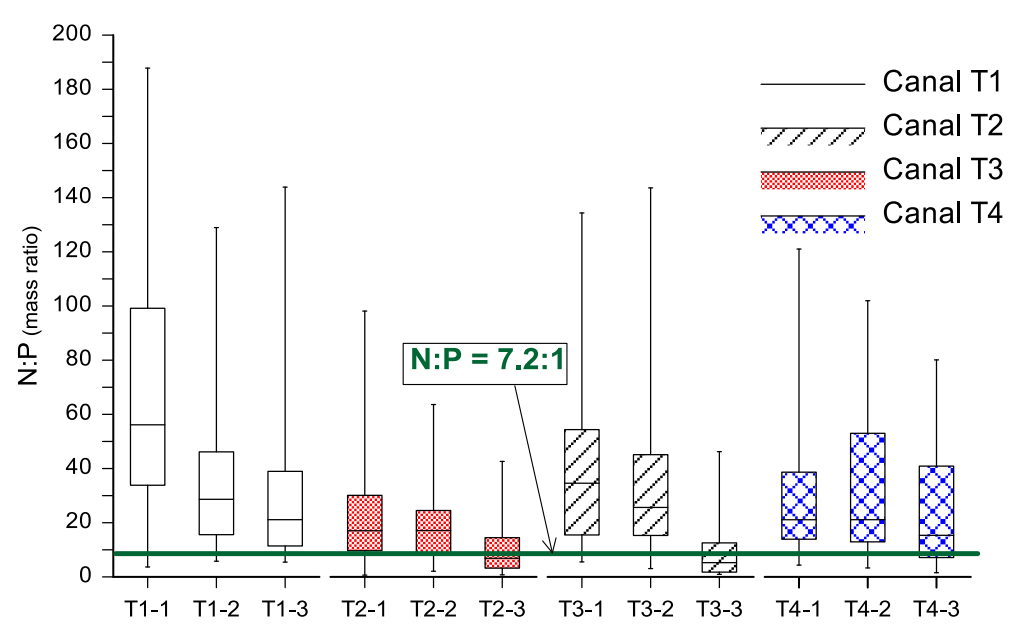

Fig. 4 N:P mass ratio at T1,T2, T3 and T4 canals during the monitoring period compared to the ratio of 7.2:1

T4-1, T4-2 and T4-3 was larger than 7.2:1 with exception of a few cases where the N/P ratio was equal to or less than 7.2:1. Therefore, phosphorus is the limiting nutrient for phytoplankton production at these canal sites. The N/P ratio at T2-3 and T3-3 presented a mixed figure, since the values were greater, less or equal to the Redfield ratio. This is due to small concentrations of $\mathrm{NO}_{\mathrm{x}}-\mathrm{N}$ at T2-3 (Fig. 3f), and high concentrations of OP and TP at T3-3 (Fig. 3h).

Table 2 presents the trophic state categories of flowing waters based on concentrations of total nitrogen (TN) and total phosphorus (TP), as proposed by Dodds et al. (1998). The trophic state category of the canals at stations T1-3, T2-3, T3-3, T4-3 (Fig. 1), based on the mean concentration of TN during the monitoring period, is mesotrophic for T1, T2 and T3 canals, and oligotrophic for T4. Based on the mean concentration of TP, the trophic state category is mesotrophic for T1 and T4, and eutrophic for T2 and T3.

Figure 5 presents the variation of the trophic state category of the canals during the monitoring period. According to the TN concentration curve: canal T1 was mesotrophic and canals T2 and T4 were oligotrophic to mesotrophic for most part of the monitoring period; for all canals there is no difference in trophic state between their upper and lower parts (i.e., stations 1 and 3); canal T3 was mesotrophic during the monitoring period at T3-1 station, and mesotrophic for most part of the monitoring period to eutophic from October 2007 to June 2008 at T3-3 station (Fig. 5, T3). According to the TP concentration curve: canal T1 was oligotrophic to mesotrophic at T1-1, and mesotrophic to eutrophic at T1-3, probably due to phosphorus loading from agriculture along the canal; canal T2 was mesotrophic to eutrophic for most part of the monitoring period, with no difference in trophic state between T2-1 and

Table 2 Trophic state category of the four canals according to the classification scheme of temperate streams (Dodds et al. 1998)

\begin{tabular}{|c|c|c|c|c|c|c|c|}
\hline \multirow[b]{2}{*}{ Parameter } & \multicolumn{3}{|c|}{ Trophic state category } & \multicolumn{4}{|l|}{ Canal } \\
\hline & Oligo-trophic (I) & Meso-trophic (II) & Eutrophic (III) & $\mathrm{T} 1-3$ & $\mathrm{~T} 2-3$ & T3-3 & T4-3 \\
\hline $\mathrm{TN}(\mu \mathrm{g} / \mathrm{L})$ & $<700$ & $700-1,500$ & $>1,500$ & 1,216 (II) & 796 (II) & 1,423 (II) & 655 (I) \\
\hline $\mathrm{TP}(\mu \mathrm{g} / \mathrm{L})$ & $<25$ & $25-75$ & $>75$ & 62 (II) & 82 (III) & 264 (III) & 42 (II) \\
\hline
\end{tabular}



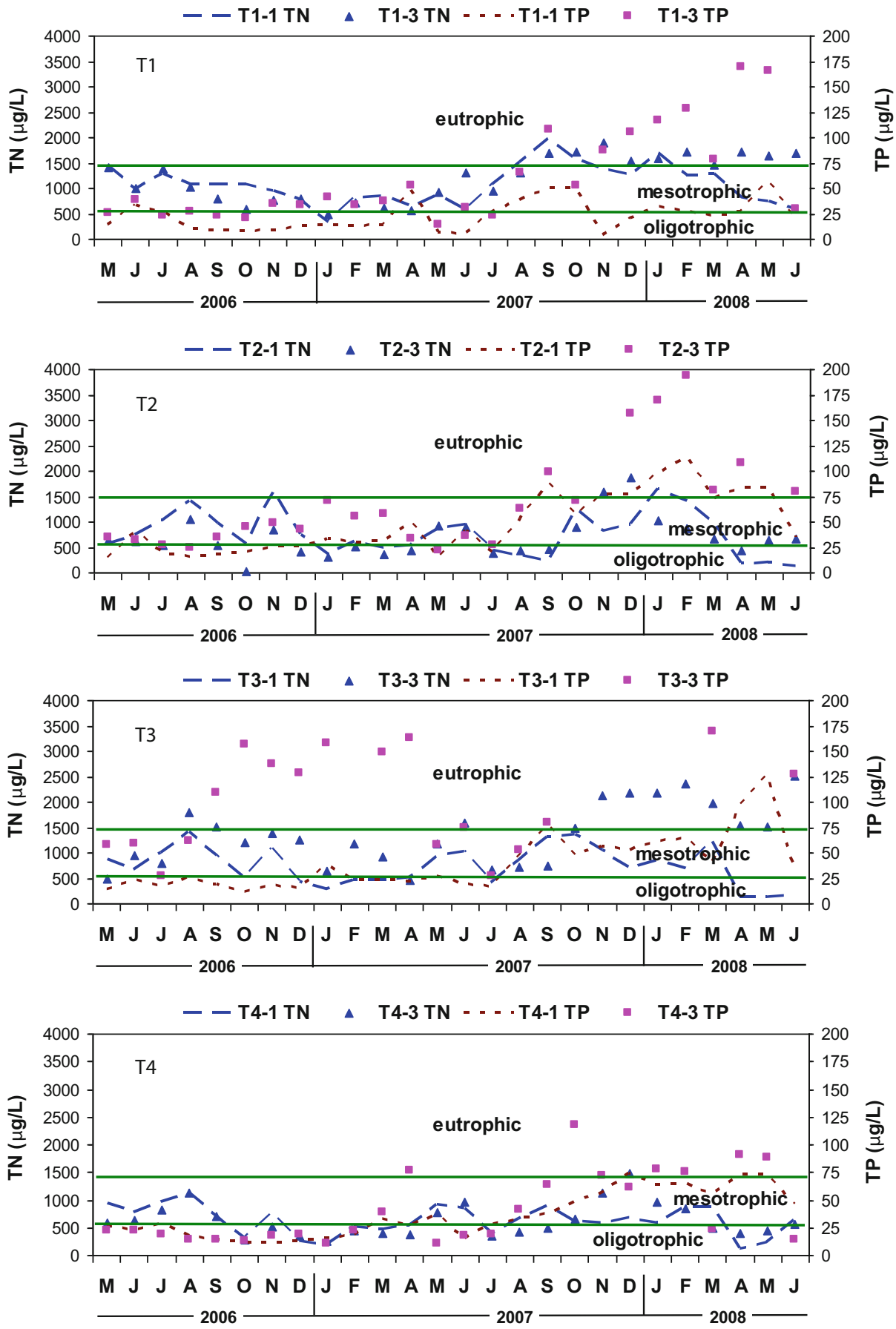

Fig. 5 Monthly variation of trophic state of canals at T1-1, T1-3, T2-1, T2-3, T3-1, T3-3 and T4-1, T4-3 during the monitoring period 
T2-3 stations, with the exception of the period from July 2006 to December 2006 where the canal was oligotrophic at T2-1 station; the trophic state of canal T3 was oligotrophic to eutrophic at T3-1 station and mesotrophic to eutrophic at T3-3 station for most part of the monitoring period, due to the influence of the poultry farm at this location; canal T4 was oligotrophic to mesotrophic at T4-1 and T4-3 stations for almost the entire monitoring period, with the exception of some instances where the trophic state at T4-3 was eutrophic (Fig. 5, T4).

\subsection{Model Calibration and Verification Results}

Figure 6 presents calibration results of the model QUAL2Kw for cultivation (29 June 2006) and non-cultivation (7 December 2006) seasons in canal T1, and Fig. 7 presents verification results for cultivation (21 June 2007) and non-cultivation (4 December 2007) periods for the same canal. Figures 6 and 7 show results estimated by the model along the canal on the particular day and compare them to those measured. The horizontal axis of each graph indicates the distance $(\mathrm{km})$ upstream of the mouth of the canal (distance 0 is the mouth). NOF values of calibration and verification for canals $\mathrm{T} 1$ and $\mathrm{T} 4$ are presented in Table 3.

As seen in Fig. 6, the model calibration for discharge for cultivation and non-cultivation periods is satisfactory, because the coefficient of NOF ( 0.25 and 0.23 , respectively) is very close to the value 0.0 (Table 3). The model verification for discharge (Fig. 7a,b) for the two periods is also satisfactory, as the value of NOF is 0.28 and 0.22 for cultivation and non-cultivation periods, respectively. Model calibration is also satisfactory for the remaining parameters: $\mathrm{pH}, \mathrm{EC}, \mathrm{OP}, \mathrm{NO}_{3}-\mathrm{N}$ and $\mathrm{NH}_{4}-\mathrm{N}$, as shown in Fig. 6. NOF values for all parameters in the model calibration are less than 1.0 and close to 0.0 (Table 3), indicating a very satisfactory performance. The results of the model verification are also satisfactory for all parameters. In Fig. 7a,b, values predicted by the model are very close to those measured in the field, with the exceptions of orthophosphates and ammonium nitrogen, whose fate is not simulated very well at the mouth of the canal, possibly because of the tide and, generally, the influence of the seawater. In the case of ammonium nitrogen, the model overestimates the concentration, while in the case of nitrate nitrogen the model underestimates the nitrogen concentration. Nevertheless, the value is acceptable, since NOF is less than 1.0 (Table 3). Calibration and verification are also satisfactory for canal T4, since NOF values are less than 1.0 for all parameters (Table 3).

\subsection{Estimation of Nutrient Loads from Non-point Sources into the Canals}

As mentioned above, for the calibration of the model, nutrient loads were added, in order to minimize differences between estimated by the model and measured in the field values. Figure $8 \mathrm{a}, \mathrm{b}$ shows the loads of nutrients $(\mathrm{N}, \mathrm{P})$ added to each reach of canal T1 in June 2006 (cultivation season) from non-point sources. The nitrate nitrogen loads range from $657 \mathrm{~kg}$ in reach 7 (S-7) to $990 \mathrm{~kg}$ in S-13 (Figs. 3, 8a). The load of the ammonium nitrogen range from $193 \mathrm{~kg}$ to $887 \mathrm{~kg}$ in S-3 and S-12 reaches, respectively (Fig. 8a). The total load of nitrogen entering into the canal from non-point sources is $7,427 \mathrm{~kg}$ and $5,306 \mathrm{~kg}$ for ammonium and nitrate nitrogen, respectively. Regarding ortho-phosphate phosphorus, the greatest influx occurs at the entrance points of the canal (reaches S-3, S-4, S-5) and is less than that in the remaining reaches (Fig. 8b). The total amount of phosphorus that enters the canal 

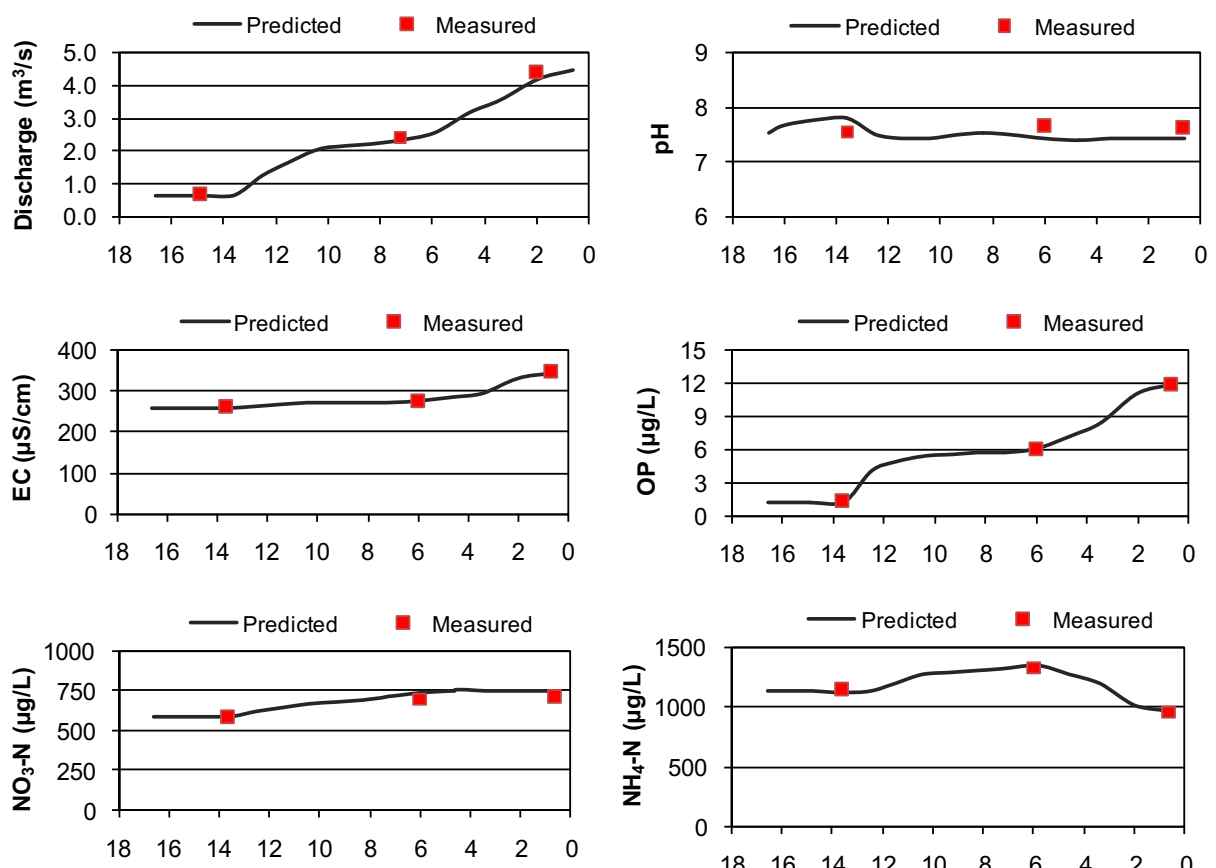

(a) Distance from estuary $(\mathrm{km})$
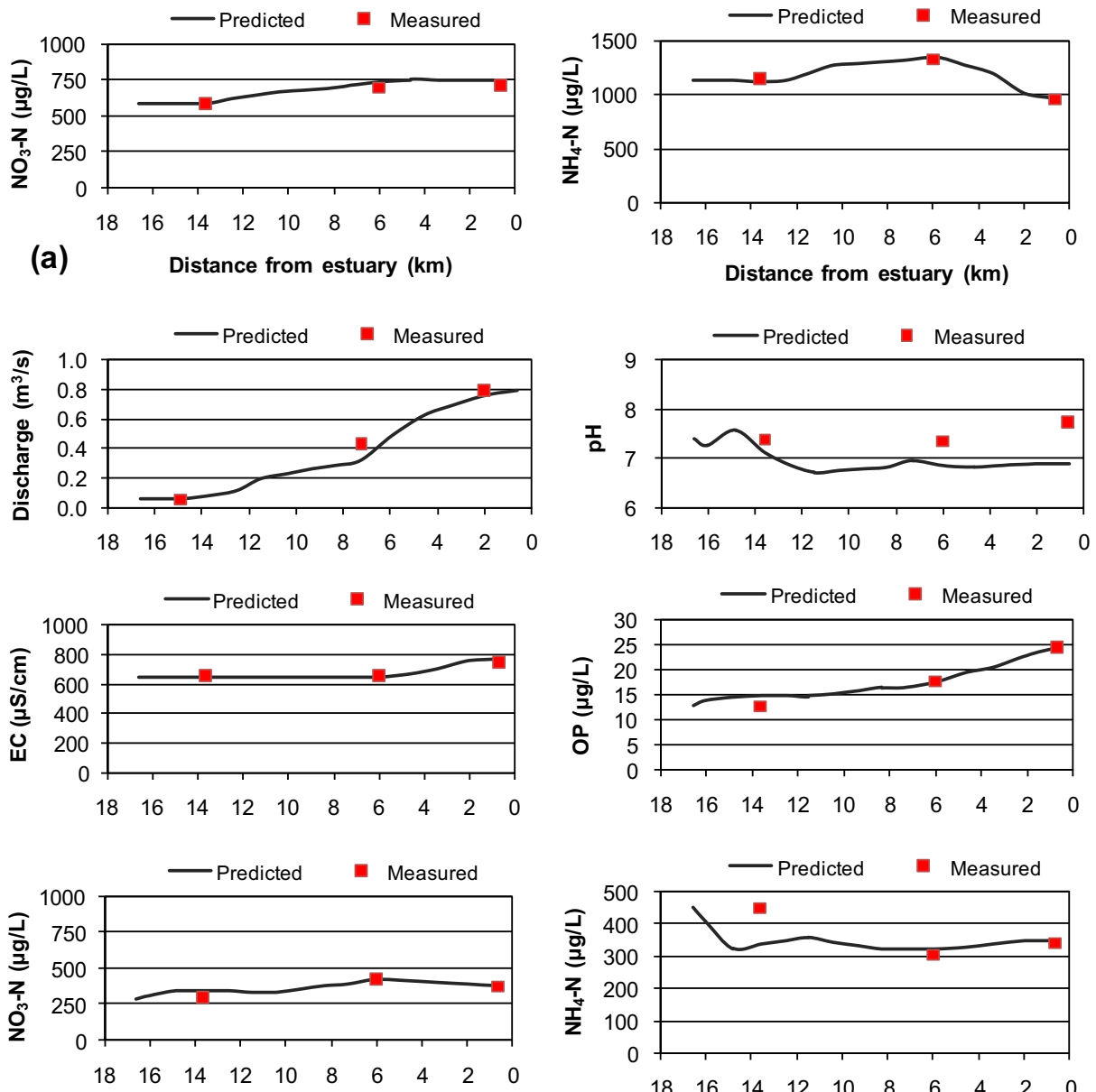

(b)

Distance from estuary $(\mathbf{k m})$

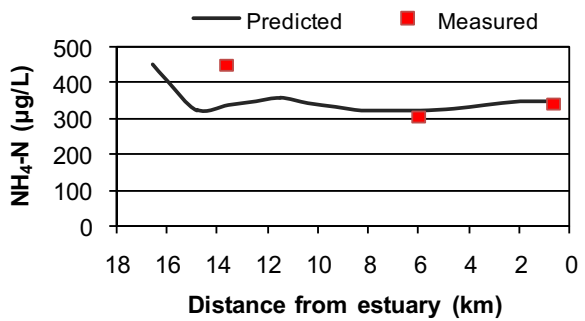

Fig. 6 Model calibration for T1 drainage canal: a for cultivation season (29 June 2006); and b for noncultivation season (7 December 2006) 

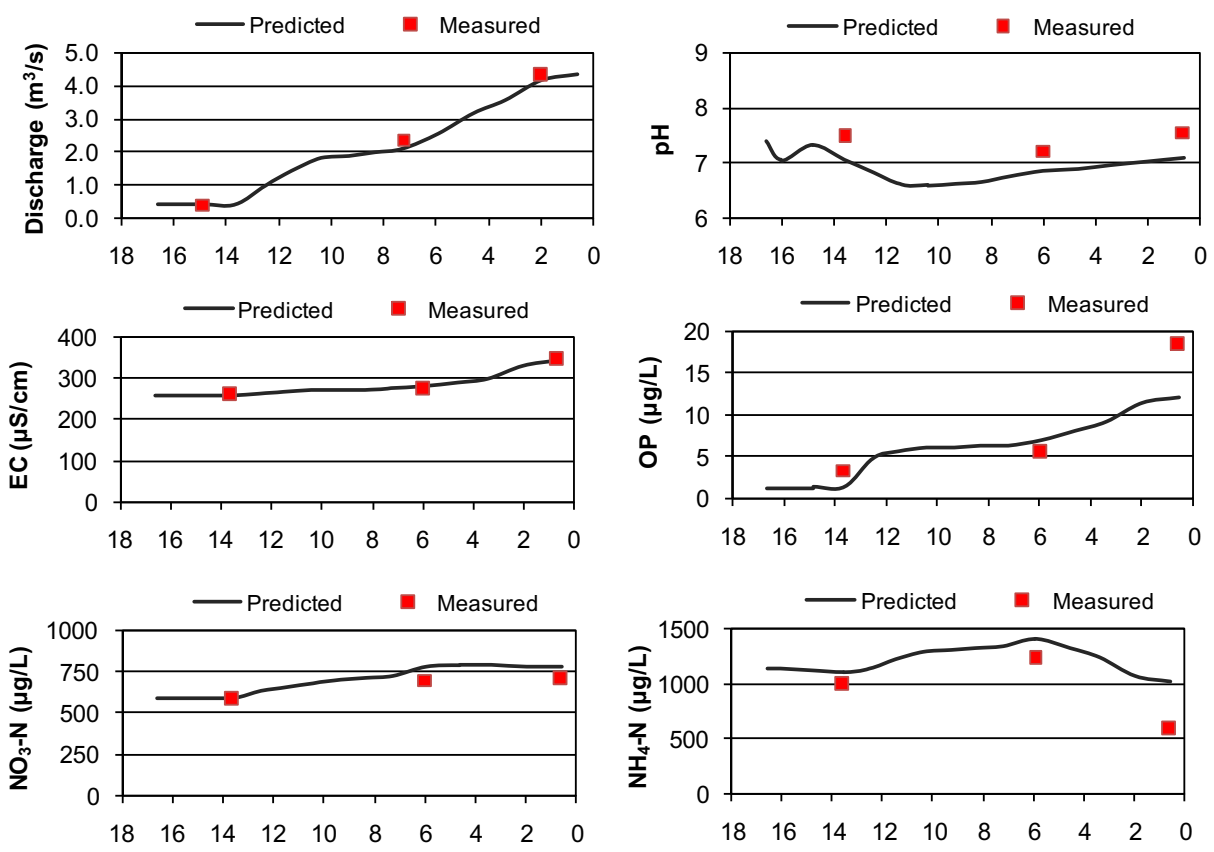

(a) Distance from estuary $(\mathrm{km})$

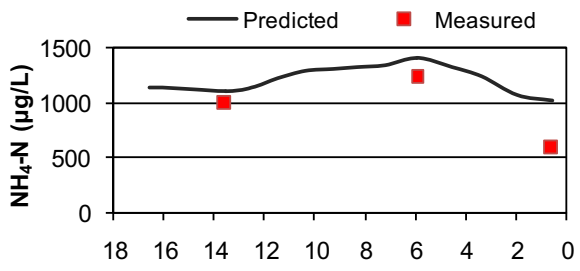

Distance from estuary (km)
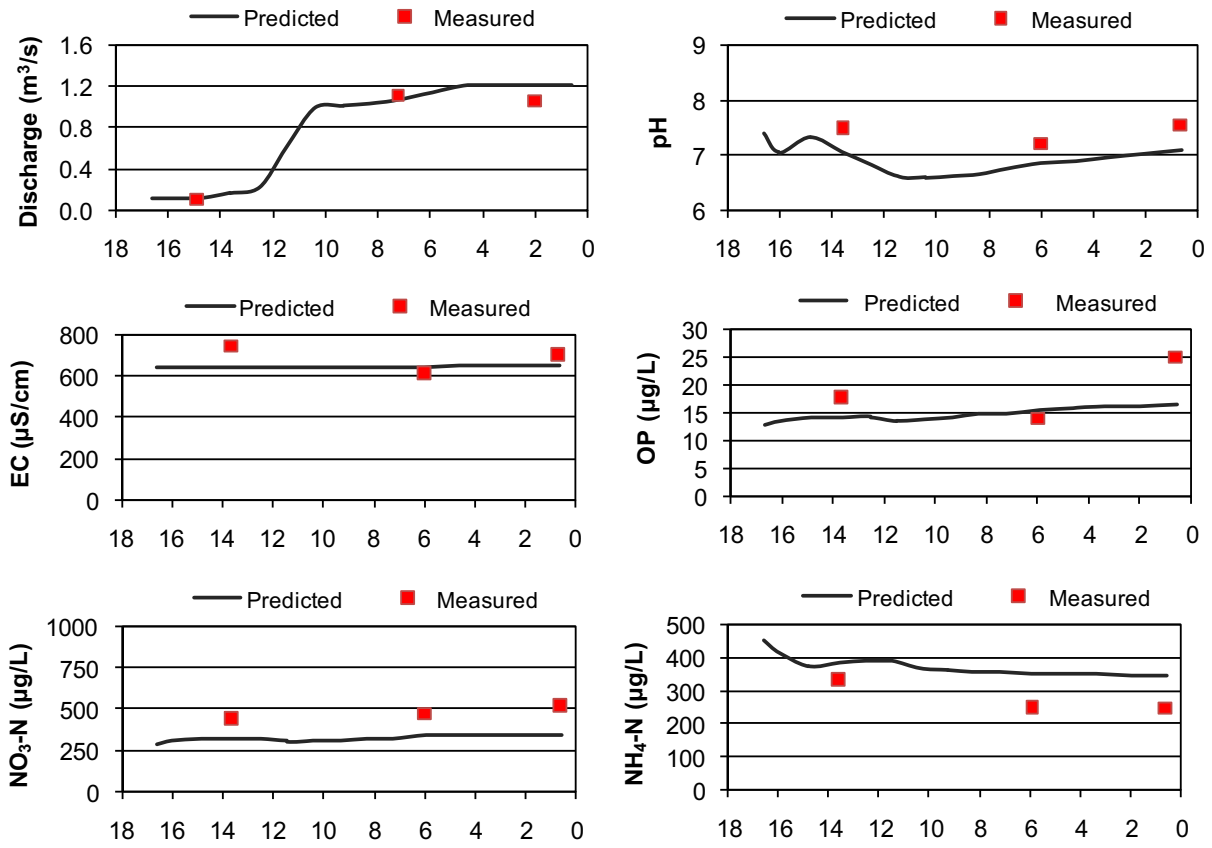

(b)

Distance from estuary $(\mathrm{km})$

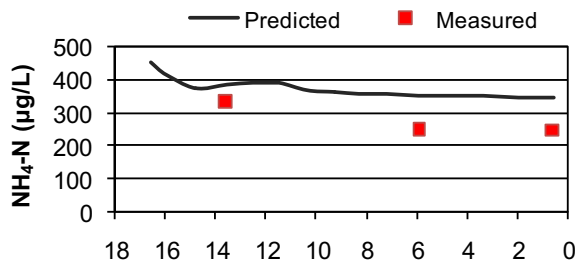

Distance from estuary (km)

Fig. 7 Model verification for T1 drainage canal: a for cultivation season (21 June 2007); and b for noncultivation season (4 December 2007) 
Table 3 NOF values for calibration and verification of the model in T1 and T4 canals

\begin{tabular}{|c|c|c|c|c|c|c|}
\hline \multirow{3}{*}{ Parameter } & \multicolumn{3}{|l|}{ Calibration } & \multicolumn{3}{|l|}{ Verification } \\
\hline & \multirow[t]{2}{*}{ Date } & \multicolumn{2}{|l|}{$\mathrm{NOF}$} & \multirow[t]{2}{*}{ Date } & \multicolumn{2}{|l|}{$\mathrm{NOF}$} \\
\hline & & $\mathrm{T} 1$ & $\mathrm{~T} 4$ & & $\mathrm{~T} 1$ & $\mathrm{~T} 4$ \\
\hline Discharge & $29 / 06 / 2006$ & 0.25 & 0.15 & $21 / 06 / 2007$ & 0.28 & 0.27 \\
\hline $\mathrm{pH}$ & & 0.19 & 0.21 & & 0.33 & 0.42 \\
\hline $\mathrm{EC}$ & & 0.11 & 0.04 & & 0.25 & 0.34 \\
\hline OP & & 0.21 & 0.12 & & 0.84 & 0.51 \\
\hline $\mathrm{NO}_{3}-\mathrm{N}$ & & 0.15 & 0.27 & & 0.21 & 0.33 \\
\hline $\mathrm{NH}_{4}-\mathrm{N}$ & & 0.21 & 0.34 & & 0.52 & 0.68 \\
\hline Discharge & $7 / 12 / 2006$ & 0.23 & 0.11 & $4 / 12 / 2007$ & 0.22 & 0.18 \\
\hline $\mathrm{pH}$ & & 0.38 & 0.11 & & 0.66 & 0.51 \\
\hline $\mathrm{EC}$ & & 0.13 & 0.14 & & 0.19 & 0.42 \\
\hline OP & & 0.18 & 0.22 & & 0.52 & 0.47 \\
\hline $\mathrm{NO}_{3}-\mathrm{N}$ & & 0.13 & 0.15 & & 0.43 & 0.35 \\
\hline $\mathrm{NH}_{4}-\mathrm{N}$ & & 0.31 & 0.14 & & 0.62 & 0.55 \\
\hline
\end{tabular}

T1 from non-point sources in June 2006 is $114 \mathrm{~kg}$. The total amount of ammonium and nitrate nitrogen entering the canal from non-point sources (Fig. 8c,d) in December 2006 (non-cultivation period) is $924 \mathrm{~kg}$ and $937 \mathrm{~kg}$, respectively. For the same period

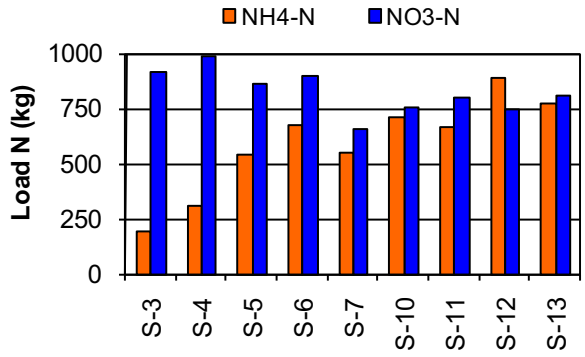

(a)

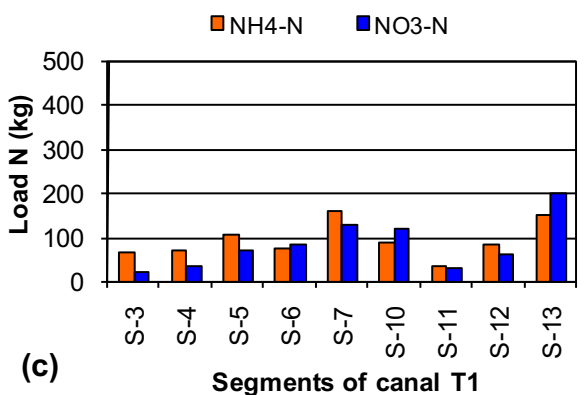

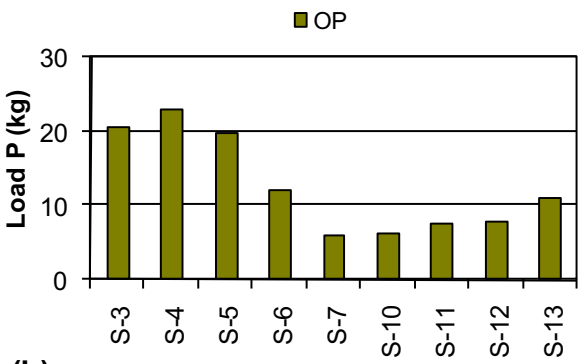

(b)

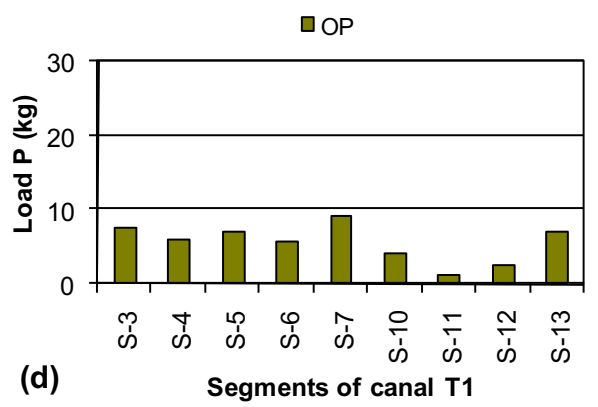

Fig. 8 Nutrient load from non-point sources into canal T1 in June 2006: a nitrate and ammonium nitrogen; and b ortho-phosphate phosphorus; and in December 2006: c nitrate and ammonium nitrogen; and d ortho-phosphate phosphorus 
Table 4 Export coefficients for nutrients (N, P) from agricultural areas

\begin{tabular}{llll}
\hline Land use type & $\mathrm{N}(\mathrm{kg} / \mathrm{ha}-\mathrm{yr})$ & $\mathrm{P}(\mathrm{kg} / \mathrm{ha}-\mathrm{yr})$ & Reference \\
\hline Agriculture & 17.86 & 0.21 & This study \\
Agriculture & 24.21 & 0.82 & Pieterse et al. (2003) \\
Agriculture & $7.90(3.2-33.3)^{*}$ & $1.44(0.2-6.8)^{*}$ & Frinc (1991) \\
Mixed agriculture & $14.00(9.0-25.5)^{*}$ & $1.00(0.5-1.5)^{*}$ & Young et al. (1996) \\
\hline
\end{tabular}

* range

the total amount of phosphorus is $60 \mathrm{~kg}$. The loads of ammonium and nitrate nitrogen entering the canal during the cultivation period (June) compared to that in the noncultivation period (December) are 8.0 and 5.7 times greater, respectively. Regarding the phosphorus load during the cultivation period, it is two times greater than that of the non-cultivation period.

These values of nitrogen and phosphorus loadings to the canals are considered high. A probable cause for this is the intense fertilization of the area. The average application rate for $\mathrm{N}$ and $\mathrm{P}$ is $226.30 \mathrm{~kg} / \mathrm{ha}-\mathrm{yr}$ and $57.45 \mathrm{~kg} / \mathrm{ha}-\mathrm{yr}$, respectively (Table 1). Based on the results of model calibration for canals T1 and T4, the export coefficient (loading factor) was estimated at $17.86 \mathrm{~kg} \mathrm{~N} / \mathrm{ha}-\mathrm{yr}$ and $0.21 \mathrm{~kg} \mathrm{P} / \mathrm{ha}-\mathrm{yr}$ (Table 4). The export coefficients in the river Dommel watershed (Netherlands and Belgium) for $\mathrm{N}$ and $\mathrm{P}$, reported by Pieterse et al. (2003), were $24.21 \mathrm{~kg} / \mathrm{ha}-\mathrm{yr}$ and $0.82 \mathrm{~kg} / \mathrm{ha}-\mathrm{yr}$, respectively. These values are higher compared to those of the present study, probably due to the application rates in Dommel area $(448 \mathrm{~kg} \mathrm{~N} / \mathrm{ha}-\mathrm{yr}$ and $76 \mathrm{~kg} \mathrm{P} / \mathrm{ha}-\mathrm{yr}$ ), which exceeded the rates in our study area. However, the export coefficients of Chryssoupolis plain and Dommel area are consistent with the literature values, which range from 3.2 to $33.3 \mathrm{~kg} / \mathrm{ha}-\mathrm{yr}$ (median value 7.9 ) for nitrogen, and from 0.2 to $6.8 \mathrm{~kg} / \mathrm{ha}-\mathrm{yr}$ (median value 1.44) for phosphorus (Frinc 1991; Young et al. 1996).

\section{Conclusions}

In terms of water quality, drainage canal monitoring showed increased nutrient concentrations downstream of intensively cultivated areas, leading to water pollution. The present study showed that the model QUAL2Kw can simulate flow and water quality parameters in the drainage canals of Chryssoupolis plain. Based on the calibration of the model for cultivation and non-cultivation periods, loads of nutrients $(\mathrm{N}, \mathrm{P})$ entering into the canals $\mathrm{T} 1$ and $\mathrm{T} 4$ from non-point sources were estimated. The cultivation season loads of nitrogen and phosphorus entering into the canal are multiples of the loads entering during the non-cultivation season. Also, it was found that certain canal reaches accept larger loads, something that helps in indentifying pollutant sources and in taking appropriate best management measures to reduce pollution. This can be done with appropriate guidance to farmers for proper crop fertilization. Other management measures may also include the installation of riparian vegetation and buffer strips along the canals. These have been found very effective in preventing non-point source pollution from agricultural areas from entering canals and rivers. Finally, the use of constructed wetlands for the treatment of agricultural runoff 
could improve the quality of water discharged into canals and coastal lagoons, since they are very efficient and inexpensive solutions to reduce nutrients.

\section{References}

APHA, AWWA (1998) Standard Methods for the Examination of Water and Wastewater, 20th Edition. Washington D.C., USA

Boskidis I, Gikas GD, Pisinaras V, Tsihrintzis VA (2010) Spatial and temporal changes of water quality, and SWAT modeling of Vosvozis river basin, North Greece. J Environ Sci Health-Part A 45(11):1421-1440

Boskidis I, Gikas GD, Sylaios G, Tsihrintzis VA (2011) Water quantity and quality assessment of lower Nestos river, Greece. J Environ Sci Health-Part A 46:1050-1067

Boskidis I, Gikas GD, Sylaios G, Tsihrintzis VA (2012) Hydrologic and water quality modeling of lower Nestos river basin. Water Resour Manag 26:3023-3051. doi:10.1007/s11269-012-0064-7

Bottino F, Ferraz IC, Mendiondo EM, Calijuri MC (2010) Calibration of QUAL2K model in Brazilian micro watershed: effects of the land use on water quality. Acta Limnol Brasiliensia 22(4):474-485

Chapra S, Pelletier G, Tao H (2008) QUAL2K: A modeling framework for simulating river and stream water quality, Version 2.11: Documentation and users manual. Civil and Environmental Engineering Dept., Tufts University, Medford, MA

Chapra SC, Pelletier GJ (2003) QUAL2K: A modeling framework for simulating river and stream water quality (Beta Version): Documentation and users manual. Civil and Environmental Engineering Dept. Tufts University, Medford

Chow VT (1959) Open-Channel Flow. McGraw-Hill, New York

Dodds WK, Jones JR, Welch EB (1998) Suggested classification of stream trophic state: Distributions of temperate stream types by chlorophyll, total nitrogen, and phosphorus. Water Res 32:1455-1462

Fan C, Ko C, Wang W (2009) An innovative modeling approach using QUAL2K and HEC-RAS integration to assess the impact of tidal effect on river water quality simulation. J Environ Manag 90:1824-1832

Frinc CR (1991) Estimating nutrient exports to estuaries. J Environ Qual 20:717-724

Gikas GD, Yiannakopoulou T, Tsihrintzis VA (2006a) Modeling of non-point source pollution in a Mediterranean drainage basin. Environ Model Assess 11:219-233

Gikas GD, Yiannakopoulou T, Tsihrintzis VA (2006b) Water quality trends in a coastal lagoon impacted by nonpoint source pollution after implementation of protective measures. Hydrobiologia 563:385-406

Gikas GD, Yiannakopoulou T, Tsihrintzis VA (2009a) Hydrodynamic and nutrient modeling in a Mediterranean coastal lagoon. J Environ Sci Health-Part A 44(13):1400-1423

Gikas GD, Tsihrintzis VA, Akratos CS, Haralambidis G (2009b) Water quality trends in Polyphytos reservoir, Aliakmon River, Greece. Environ Monit Assess 149(1-4):163-181

Gikas GD, Tsihrintzis VA (2012) Assessment of water quality of first-flush roof runoff and harvested rainwater. J Hydrol 466-467:115-126

Kannel PR, Lee S, Kanel SR, Lee Y, Ahn K-H (2007a) Application of QUAL2Kw for water quality modeling and dissolved oxygen control in the river Bagmati. Environ Monit Assess 125:201-217

Kannel PR, Lee S, Lee Y-S, Kanel SR, Pelletier GJ (2007b) Application of automated QUAL2Kw for water quality modeling and management in the Bagmati river, Nepal. Ecol Model 202:503-517

Kotti ME, Vlessidis AG, Thanasoulias NC, Evmiridis NP (2005) Assessment of river water quality in Northwestern Greece. Water Resour Manag 19:77-94

Novotny V, Olem H (1994) Water Quality: Prevention, Identification and Management of Diffuse Pollution. Van Nostrand Reinhold, USA

Pelletier GJ, Chapra SC, Tao H (2006) QUAL2Kw-A framework for modeling water quality in streams and rivers using a genetic algorithm for calibration. Environ Model Softw 21:419-425

Pelletier GJ, Chapra CS (2005) QUAL2Kw theory and documentation: A Modeling Framework for Simulating River and Stream Water Quality Version 5.1. Available from: http://www.ecy.wa.gov/programs/eap/models/. Access on: 7 April 2010

Pieterse NM, Bleuten W, Jorgensen SE (2003) Contribution of point sources and diffuse sources to nitrogen and phosphorus loads in lowland river tributaries. J Hydrol 271:213-225

Rehana S, Mujumdar PP (2011) River water quality response under hypothetical climate change scenarios in Tunga-Bhadra river, India. Hydrol Process 25:3373-3386

Singh KP, Malik A, Sinha S (2005) Water quality assessment and apportionment of pollution sources of Gomti river (India) using multivariate statistical techniques - a case study. Anal Chim Acta 538:355-374

Sylaios G, Theocharis V (2002) Hydrology and nutrient enrichment at two coastal lagoon systems in Northern Greece. Water Resour Manag 16:171-196 
Sylaios GK, Tsihrintzis VA, Akratos C, Haralambidou K (2006) Quantification of water, salt and nutrient exchange processes at the mouth of a Mediterranean coastal lagoon. Environ Monit Assess 119(1-3):275301

Turner DF, Pelletier GJ, Kasper B (2009) Dissolved oxygen and pH modeling of a periphyton dominated, nutrient enriched river. J Environ Eng 135:645-652

Young WJ, Marston FM, Davis RJ (1996) Nutrient exports and land use in Australian catchments. J Environ Manag 47:165-183

Wang Q, Li S, Jia P, Qi C, Ding F (2013) A Review of surface water quality models. Sci World J 2013: Article ID 231768, 7 pages (dx.doi.org/10.1155/2013/231768)

Zhang R, Qian X, Li H, Yuan X, Ye R (2012) Selection of optimal river water quality improvement programs using QUAL2K: A case study of Taihu Lake Basin, China. Sci Total Environ 431:278-285 